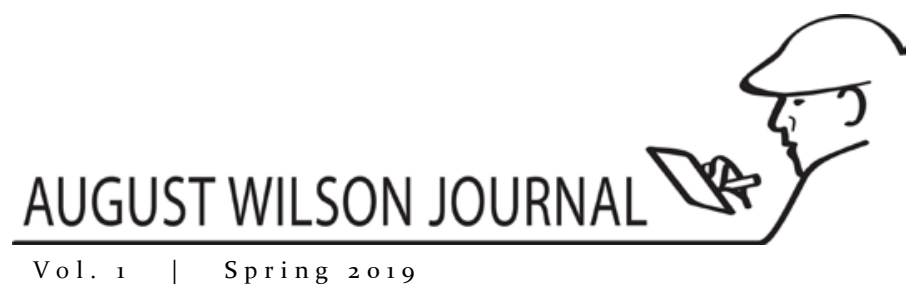

\title{
August Wilson Society President's Foreword to Inaugural Issue of the August Wilson Journal
}

\author{
By Sandra G. Shannon \\ Professor Emerita, Howard University
}

\begin{abstract}
The release of the much-anticipated inaugural issue of the August Wilson Journal is yet another indicator that the journal's namesake, the two-time Pulitzer-prize-winning playwright August Wilson, belongs to the ages.
\end{abstract}

- Sandra G. Shannon

\begin{abstract}
Founder and President of the August Wilson Society reflects upon the growth of the field of August Wilson studies over the past several decades and points towards a promising future.

Keywords

August Wilson, Sandra Shannon, Alan Nadel, The Dramatic Vision of August Wilson, Robert Brustein, August Wilson Journal, The Ground on Which I Stand, The August Wilson Society, Michael Downing, David Anderson
\end{abstract}

I discovered in the late 1980 s that August Wilson was a playwright to watch. Approximately ten years later after immersing myself in extant-though limitedscholarship on his work, I had no doubt that his plays must be required reading and that no



Sandra Shannon self-respecting high school or college curricula could afford to ignore his work. Buoyed by these certainties, I sought to make Wilson's canon as familiar and as accessible in academe as that of Shakespeare, to facilitate widespread and serious study of his plays, and to serve as a catalyst for a much-needed body of scholarship on this major American playwright. I was soon to discover that work toward these ambitious goals was daunting as I perused shelves, newspaper clippings, and databases and as I followed leads to secure key interviews and travel to sites that promised additional material to support my first book, The Dramatic Vision of August Wilson (Howard UP, 1995). ${ }^{1}$ I persevered.

Although my early-to-mid-199os search for sources on Wilson continued to be arduous, I soon detected a slow-but-steady uptick in serious treatment of what is now known as the American Century Cycle. In 1994, I expressed a mixture of cautious optimism and alarm in my "Annotated Bibliography of Works by and about August Wilson," which appeared in Alan Nadel's seminal collection, May All Your Fences Have Gates: Essays on the Drama of August Wilson (Iowa UP). ${ }^{2}$ "Critical assessment of August Wilson's plays has 
increased in scope and in momentum over the last decade," I touted in the brief introduction to my thirty-six-page project. I went on to note the following:

Although he wrote his first play in 1973 (Recycle), serious attention to his work did not come until the early 1980s with the Broadway success of Ma Rainey's Black Bottom (1981). Now, Wilson is one of the most-written-about dramatists in America, capturing the respect and admiration of some of New York's toughest critics and inspiring a well-spring of scholarly activity about the plays that make up his proposed ten-play chronicle of the black experience. Published commentary on his work has likewise evolved from an abundance of theatre reviews of works staged along a familiar path from the Yale Repertory Theatre to Broadway . . . Extensive though it may be, this annotated bibliography is not all-inclusive; it is instead intended as a starting place for anyone doing preliminary research on August Wilson. ${ }^{3}$

What began some thirty years ago as an overly ambitious agenda on my part has now evolved into a full-fledged formal enterprise! The release of the much-anticipated inaugural issue of the August Wilson Journal is yet another indicator that the journal's namesake, the two-time Pulitzer-prize-winning playwright August Wilson, belongs to the ages. Unlike many of his fellow playwrights, Wilson famously read a lot of what theatre critics (including his nemesis, New Republic critic Robert Brustein) had to say about his earlier staged performances. Some of their reviews hit below the belt. Some showed blatant cultural insensitivity, racial bias, and ignorance. Fortunately, an appreciable number of reviews provided astute, objective observations and judiciously pointed out both strengths and weaknesses in the performance and, at times, called attention to perceived flaws within the playwriting itself. The seemingly misguided tenor adopted early on by theatre reviewers led Wilson to single out critics per se in his well-publicized 1996 speech, "The Ground On Which I Stand" speech, where he writes, "As playwrights grow and develop, as the theatre changes, the critic has an important responsibility to guide and encourage that growth ... It is the critic who should be in forefront of developing new tools for analysis necessary to understand new influences. ${ }^{4}$

While Wilson's high-profile pronouncements originally targeted critics of staged performances of his work, they may also stand as ongoing reminders to today's scholars who aspire to publish research on his body of dramatic literature. The August Wilson Journal proudly accepts Wilson's nearly 25-year-old charge to critics by creating a publishing home for continued growth and excellence in scholarship in August Wilson Studies. On behalf of the August Wilson Society and as its President, I congratulate the founders of the August Wilson Journal, Michael Downing and David Anderson, and pledge our support in making it into a premiere, world-class publication.

\section{Author Bio}

Dr. Sandra Shannon is Professor Emerita at Howard University. She has published numerous books and essays on August Wilson and is the Founder and President of the August Wilson Society. 
S H A N N ON : P RES I D EN T O F T H E A U G U S T W I L S ON S OCIETY'S

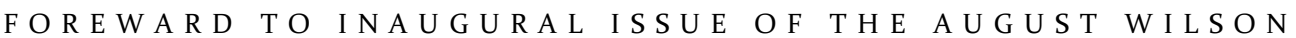
J O U R N A L

August Wilson Journal| Vol. 1 Spring 2019

\section{Notes}

${ }^{1}$ Sandra Shannon. The Dramatic Vision of August Wilson. Howard UP, 1995.

${ }^{2}$ Alan Nadel. May All Your Fences Have Gates: Essays on the Drama of August Wilson. Iowa UP, 1994, p. 230.

${ }^{3}$ Ibid, 230.

${ }^{4}$ August Wilson. The Ground On Which I Stand. Theatre Communications Group, 1996, 43-44.

c) Articles in this journal are licensed under a Creative Commons Attribution 4.0 International License.

TI This journal is published by the University Library System of the University of Pittsburgh as part of its D-Scribe Digital Publishing Program and is cosponsored by the University of Pittsburgh Press. 